Mikko-Olavi Seppälä

\section{VARASTETTU KUOLEMA (1938) POLIITTISENA ELOKUVANA}

Artikkeli tarkastelee Nyrki Tapiovaaran ohjaamaa elokuvaa Varastettu kuolema (1938) kommenttina 1930-luvun vasemmistolaisen aktivismin ja Etsivän keskuspoliisin väliselle jännitteelle. Artikkelissa analysoidaan elokuvan roolien miehitystä ja esitetään siitä uutta tietoa erityisesti suhteessa harrastajateatteriin Työväen Näyttämö. Artikkeli osoittaa, miten roolitus perustui osuviin "tyyppeihin", vaikutti elokuvan käsikirjoitukseen ja oli omiaan vahvistamaan elokuvan luentaa ironisena poliittisena aikalaiskommenttina. Samalla asemoidaan Nyrki Tapiovaaraa 1930-luvun kulttuurin kentällä.

\section{Varastettu kuolema tutkimuskohteena}

Talvisodassa kaatunut Nyrki Tapiovaara (1911-1940) ehti ohjata viisi elokuvaa, joista viimeinen jäi hänen osaltaan kesken. Häntä on pidetty suomalaisen elokuvan lahjakkuutena, jonka lupaava ura katkesi traagisesti (esim. Toiviainen 1986). Tämä artikkeli käsittelee hänen toista elokuvaansa Varastettu kuolema (1938), jonka sisältö ja vastaanotto on esitelty Suomen kansallisfilmografiassa. Käytettävissäni on ollut elokuvan tuottajan ja kuvaajan Erik Blombergin (1913-1996) leikkaama lyhennetty versio, joka valmistui levitykseen vuonna 1954. (Suomen kansallisfilmografia 1995, 250-256.)

Erik Blomberg on kertonut, että elokuvan Varastettu kuolema lähtökohtana oli Helsingin Katajanokalla vapautunut Adams-Filmin studio, jonka hän oli vuokrannut ensimmäisen oman elokuvansa tekemiseen. Lapsuudenystävä Lars Erik Carpelan (1913-1987) oli ehdottanut aiheeksi Runar Schild tin novellia "Köttkvarnen" (1919, suomeksi "Lihamylly" 1922), josta Blomberg muokkasi elokuvakäsikirjoituksen yhdessä kuvaajaystävänsä Eino Mäkisen (1908-1987) kanssa. Kokematon Blomberg kutsui ohjaajaksi Mäkisen tunteman Nyrki Tapiovaaran, jolla oli kokemusta jo teatterin sekä yhden elokuvan ohjaamisesta ja joka tunsi näyttelijöitä. Blomberg itse omaksui tuottajan ja kuvaajan roolin. Tapiovaaran tultua mukaan käsikirjoitusta muokattiin tuntuvasti ja dialogin kirjoittajaksi uusiin kohtauksiin kutsuttiin Tapiovaaran lapsuudenystävä, esikoiskirjailija Matti Kurjensaari (1907-1988). (von Bagh 1980.) Varastettu kuolema kuvattiin etupäässä Katajanokalla keväällä ja kesällä 1938 ja se tuli ensi-iltaan 4.9.1938 (Suomen kansallisfilmografia 1995).
Mikko-Olavi Seppälä, FT teatteritiede, Helsingin yliopisto
KOLLEGIALT GRANSKAD PEER-REVIEWED 
Novellin romanttiset ja jännittävät tapahtumat liittyvät sisällissodan aikaiseen talven 1918 Helsinkiin, jossa valtaa piti punainen kansanvaltuuskunta. Novellin keskushenkilönä on puolalaistaustainen Manja, joka salakuljettaa kaupungilla venäläisiltä hankkimiaan aseita, asekauppias Johnnie Claesson sekä valkoisten maanalaista asehankintaa ja kuljetusta organisoiva ylioppilas Robert Hedman, johon Manja palavasti rakastuu. Tapiovaaran aloitteesta tapaukset siirrettiin Venäjän vuoden 1905 vallankumousta välittömästi edeltävään niin sanottuun venäläistämisaikaan. Novellin maanalaiset valkoiset ovatkin elokuvassa aktivisteja, aseellisen vastarinnan kannattajia, joita vastassa on Venäjän hallituksen ankara santarmihallinto ja salaisen poliisin eli ohranan urkkijat. Novellista on jäänyt elokuvaan ainoastaan eräitä Robertin, Manjan ja Claessonin keskinäisiä kohtauksia. Dramaturgisia muutoksia on yksityiskohtaisesti käsitellyt Henrik Rosenberg (1995).

1930-luvun suomalaista elokuva-alaa käsittelevässä tutkimuksessa on osoitettu, miten voimakkaasti ideologinen sensuuri karsi maahan suunnattua elokuvatarjontaa (Mickwitz 1995; Sedergren 1999; Hupaniittu \& Piispa 2015; Piispa 2017). Elokuvatutkimuksessa nimenomaan historiallista elokuvaa on tulkittu poliittisena lajityyppinä, joka enemmän tai vähemmän suorasukaisesti ilmentää oman tekoaikansa ideologioita ja suodattaa niitä populaarikulttuuriin. Leger Grindon erittelee motiiveja, minkä vuoksi elokuva on sijoitettu historiaan: 1) pyritään tekemään vaikutus auktoriteetteihin autenttisella historian kuvittamisella; 2) pyritään verhoamaan historiaan elokuvan tekoaikaa koskevat tulkinnat ja välttämään poliittinen sensuuri; 3) kyseessä on regressiivinen pako nostalgiaan; 4) etsitään historiallista totuutta tai alkuperää. (Grin-

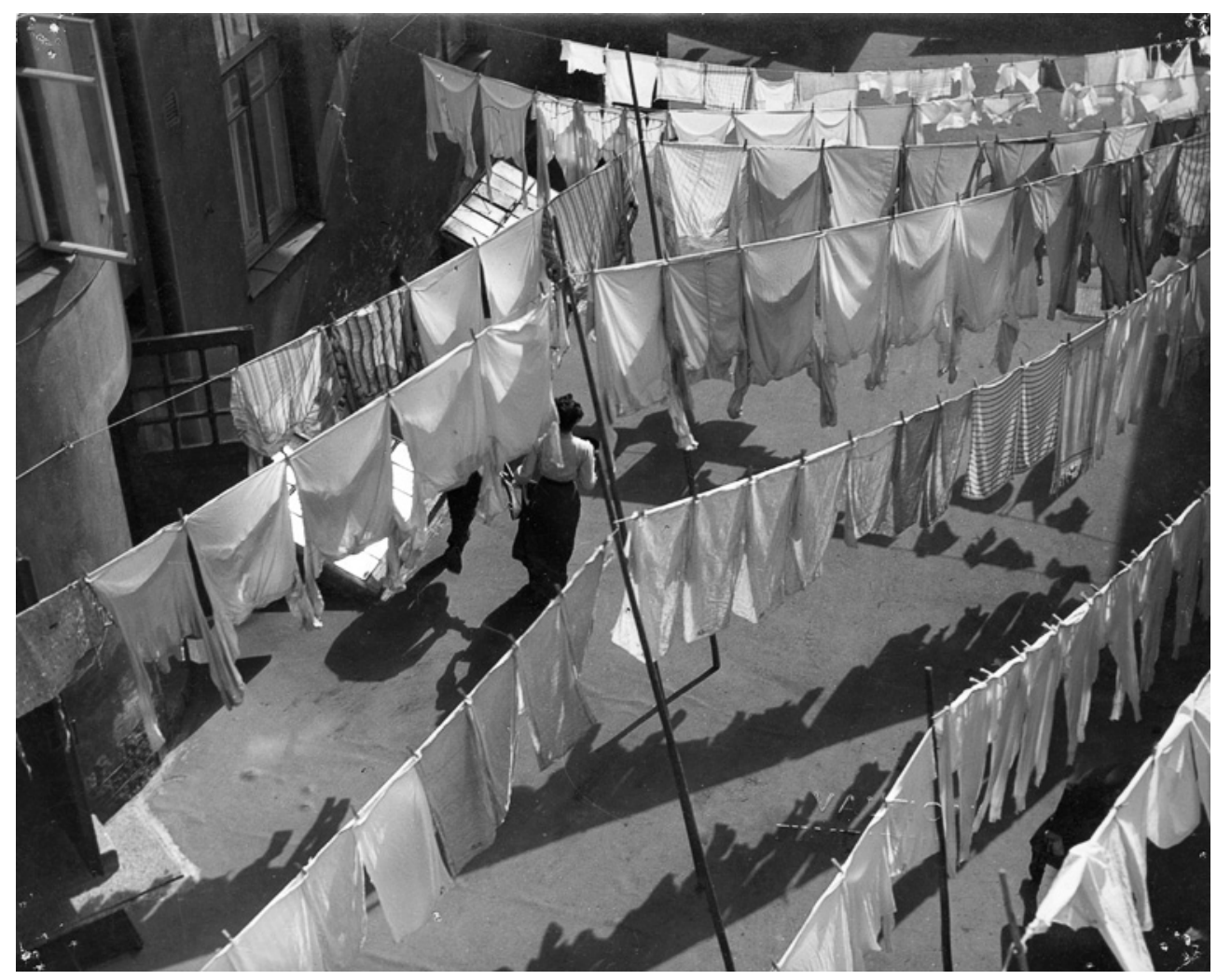

Nyrki Tapiovaaran elokuvassa Varastettu kuolema (1938) nähtiin ranskalaisen elokuvan, erityisesti René Clairin, vaikutteita. Kuva: KAVI 
don 1994, 1-3.) Grindonin motiiveista toinen luonnehtii osuvasti Varastettua kuolemaa, jossa poliittinen kommentaari on verhottu historialliseen aiheeseen.

Rajaudun tässä artikkelissa käsittelemään sitä, millä tavoin Varastettu kuolema liittyy oman valmistumisaikansa jännitteisiin, erityisesti 1930-luvun kansalaisoikeusliikkeen hankauksiin ajan repressiivisen hallituspolitiikan ja Etsivän keskuspoliisiin kanssa. Tarkastelen Varastettua kuolemaa siis poliittisena elokuvana - näkökulma, jota aikaisemmassa tutkimuksessa ei ole tyhjentävästi käsitelty ja joka on nähdäkseni elokuvan tulkinnan kannalta olennainen. Käsittelen kysymystä lähinnä roolituksen näkökulmasta. Lähtökohtani ovat teatterintutkimuksessa: olen selvittänyt Kansan arkistoon, Etsivän keskuspoliisiin arkistoon sekä aikalaislehdistöön tukeutuen yksityiskohtaisesti 1930-luvun Työväen Näyttämön ja sen henkilökunnan toimintaa ja löytänyt Varastettuun kuolemaan mielenkiintoisia yhtymäkohtia, joita ei ole huomioitu aikaisemmassa tutkimuksessa. Olen voinut muun muassa yksilöidä miltei kaikki elokuvassa esiintyvät henkilöt, mikä avaa mahdollisuuden analysoida elokuvan roolitusta entistä tarkemmin.

Varastettua kuolemaa koskevassa aikaisemmassa tutkimuksessa on pohdiskeltu sen suhdetta 1930-luvun kommunismiin. Analyysissaan Kinisjärvi, Rossi ja Kejonen (1979) toteavat yleisluontoisesti, että historiallisen ajankuvan väljyys, 1930-luvun todellisuus ja Tapiovaaran poliittiset sympatiat ruokkivat tämänsuuntaista tulkintaa. He päätyvät vertailussaan kuitenkin skeptisiin tuloksiin: elokuvan aktivistit ovat heidän mukaansa pieni ja eristynyt ryhmä ruotsinkielistä yläluokkaa vailla kontakteja "kansan syviin riveihin". Heidän mukaansa "kommunistien maanalainen toiminta lepäsi huomattavasti useammilla harteilla kuin filmin aktivisteilla ja oli tiukasti organisoitua". Erityisen silmiinpistävää oikeaoppisesta vasemmistolaisesta näkökulmasta on, että elokuva ei paljasta luokkaristiriitoja. (Kinisjärvi \& al. 1979, 34.)

Sakari Toiviainen $(1986,58)$ viittaa samaan artikkeliin ja summaa: "Tosiasiat eivät siis anna paljonkaan tukea Varastetun kuoleman 'vasemmistolaiselle' tulkinnalle, joka voi tapahtua lähinnä elämyksellistä tietä". Anneli Lehtisalo sivuaa kysymystä opinnäytteessään ja toteaa, että "elokuvasta itsestään ei löydy tarpeeksi viitteitä aktivistien ja kommunistien rinnastamiseksi". Mikäli Tapiovaara yleensä esitti yhteiskunnallista ajan "piilokritiikkiä", sen pystyivät Lehtisalon mukaan havaitsemaan "luultavasti vain ne, jotka tunsivat Tapiovaaran taustat tai ne, jotka jakoivat hänen yhteiskunnalliset näkemyksensä". (Lehtisalo 1995, 59-60.) Toisin sanoen tutkimusperinteessä on jätetty elokuvan mahdollinen poliittisuus elämyksen tietä koettavaksi tai ainoastaan sisäpiiriläisten ymmärrettävissä olevaksi, väistämättä piiloon jääväksi sfääriksi.

Elokuvia Varastettu kuolema ja Aktivistit (1939) vertaillut Matti Salakka on kiinnittänyt huomiota siihen, miten viimeksi mainittu Risto Orkon kuvakerronnaltaan sovinnainen elokuva kuvaa aktivistit avoimesti toimivina itsenäisyystaistelijoina ja tulee samalla pönkittäneeksi valmistumisaikansa hegemoniaa. Tätä vasten Salakka korostaa Varastetun kuoleman kokonaisvaltaisesti vastahistoriallista otetta: "Tapiovaaran elokuvassa taas aktivistit toimivat kuten vastarintaliikkeen jäsenet: piilossa, maan alla ja pimeässä. Näin ollen sama vastahistoriallisuus ja alistettujen ryhmien näkökulmasta kuvaaminen, joka on ominaista Varastetun kuoleman kerrontatavalle ja historian analyysille tulee esiin myös esteettisesti." (Salakka 1992, 43.) Aikalaiset korostivat Tapiovaaran ohjauksissa ranskalaisen elokuvan tyylivaikutteita; Lauri Piispa $(2017,16)$ on nähnyt sekä Varastetussa kuolemassa että Orkon Aktivisteissa ajan neuvostoelokuvien vaikutusta. 
Aikaisemmassa tutkimuksessa on liikaa juututtu pohtimaan elokuvan aktivistien suhdetta 1930-luvun kommunisteihin, eikä pohdiskelu ole kaikilta osin perustunut realistiselle kuvalle 1930-luvun kommunismista. Sinänsä elokuvan nuorten aktivistien seikkailuhenkinen toiminta, poliittista kiihotusta sisältävien lentolehtisten painaminen ja levittäminen, vastaa sangen hyvin 1930-luvun nuorkommunistien toimintaa, vaikka jälkimmäinen tapahtuikin yksinomaan työläisten piirissä. Nimenomaan poliittiseen toimintaan kiihottavien lentolehtisten kirjoittamisesta, levittämisestä tai hallussapidosta usea Työväen Näyttämön piirissä toimiva työläisnäyttelijä oli tuomittu vankeuteen. Ohranaan vertautuva Etsivä keskuspoliisi selvitti ja seurasi herkeämättä epäilyttävien henkilöiden ja heidän hallussaan olevien kirjapainovälineiden ja kirjoituskoneiden liikkeitä. (Kössi Leinon, Edvin Lindholmin, Yrjö Nykäsen ja Hulda Virtasen Henkilömapit, EK-Valpo, KA.) Uhkakuva kommunistien aseellisesta vallankumouksesta oli olemassa, mutta se ei perustunut realismiin: kommunistit olivat 1930-luvun Suomessa marginaalinen ja hajalle lyöty ryhmä, ja Stalinin vainot 1937-1938 tekivät selvää jälkeä puolueen organisaatiosta myös Neuvostoliitossa. (Rentola 2002.)

Hedelmällisempää on tarkastella elokuvaa ja sen kuvaamia aktivisteja laveammin suhteessa 1930-luvun aktivismiin, joka pyrki kokoamaan liberaaleja ja sosialisteja yhdistävää kansanrintamaa fasisminvastaiseen taisteluun sekä kamppailemaan kansalaisoikeuksien puolesta. Kansanrintama (popular front) oli Neuvostoliiton tukema kansainvälinen liike, joka pyrki Saksan natsien valtaannousun jälkeen kokoamaan vasemmistolaisia ja liberaaleja ryhmiä fasismin ja sodanvastaiseen taisteluun. Monessa maassa liike sai laajan kannatuksen ja vasemmistopuolueiden kannatus nousi; Ranskassa kansanrintamahallitus oli vallassa 1936-1937. Suomessa kansanrintamapyrkimykset paljolti torjuttiin, koska ne nähtiin yksioikoisesti kommunistien pussiin pelaamisena: Etsivä keskuspoliisi piti toimintaa Neuvostoliiton valtapyrkimyksiä tukevana valtiovehkeilynä ja Sosialidemokraattinen puolue hajotusyrityksenä. Suomessa kansanrintamaliike ylitti puoluerajoja lähinnä kamppailussaan rauhan ja sananvapauden sekä ihmis- ja kansalaisoikeuksien puolesta tilanteessa, jossa niin sanotut pakkolait uhkasivat viedä myös Suomea totalitaariseen suuntaan. (Saarela 2002, 50-51; Rentola 2002, 64-66.)

Tähän laajempaan aktivistiseen liikkeeseen Varastetun kuoleman ohjaaja Nyrki Tapiovaara ja käsikirjoittaja Matti Kurjensaari myös itse kuuluivat. Tällöin vertailu osoittautuu antoisammaksi ja yhtymäkohdat selvemmiksi, kuten pyrin seuraavassa osoittamaan.

\section{Työväen Näyttämö, aktivistien teatteri}

Nyrki Tapiovaaran elämänkulun ja -työn ovat tarkasti kirjanneet Sakari Toiviainen (1986) ja Matti Rinne (2011). Tapiovaara kasvoi vauraassa suurperheessä Hämeenlinnassa, tuli ylioppilaaksi yhdessä isoveli Tapio Tapiovaaran kanssa ja jakoi tämän kanssa opiskelijaboksinsa Helsingissä. Ateneumissa opiskellut Tapio ryhtyi kuvataiteilijaksi, Nyrki puolestaan vaihtoi lakiopinnot taideaineisiin, ohjasi teatterikappaleita ja työskenteli teatteri- ja elokuvakriitikkona. Molemmille muodostui aatteellisen kehityksen tärkeäksi lähtökohdaksi toimittaja Erkki Valan (1902-1991) johtama Tulenkantajain seura, jota elähdytti pasifistinen paneurooppalainen, ihmiskunnan veljeyttä julistava aate ja kansainvälisyys. Valan julkaisema Tulenkantajat-lehti levisi verraten laajalle ja sai viranomaisia ja hallituksen politiikkaa kritisoivasta kirjoittelus- 
taan useita painokanteita. Puoluepoliittisesti sitoutumaton ryhmä leimattiin "kulttuurivasemmistolaiseksi". Eräät sen jäsenistä ryhtyivät opiskelemaan marxismia Akateemisen Sosialistiseuran (ASS) riveissä, ja myös Vala liittyi sosialidemokraatteihin. Akateemiset sosialistit kääntyivät työläisten puoleen, vetivät työläisnuorten opintopiirejä, johtivat puhekuoroja ja osallistuivat puheillaan ja teoksillaan lakkotaisteluihin. Heidän äänitorvikseen muodostuivat ASS:n julkaisema Soihtu, Jarno Pennasen julkaisema Kirjallisuuslehti sekä Arvo Turtiaisen perustama kirjailijaryhmä Kiila. (Rinne 2006; Koivisto 2011.)

Vasemmistoälymystön ja työläisten keskeinen yhteinen toiminta-alusta oli Työväen Näyttämö -niminen harrastajateatteri, jota tulenkantajat ja akateemiset sosialistit johtivat vuosina 1934-1939. Työväen Näyttämön toimintaa ovat eri yhteyksissä selvittäneet Raija-Sinikka Rantala (1970), Tytti Oittinen (1977), Matti Rinne (2006) ja Hanne Koivisto (2011), mutta hieman epätarkasti, joten tukeudun tässä artikkelissa alkuperäisaineistoon. Etsivä keskuspoliisi piti luokkatietoista näytelmäseuraa vanhastaan kommunistien pesäpaikkana ja seurasi sen jäseniä (Raportti 19.1.1932, Hulda Virtasen henkilömappi, EKValpo, KA). Kommunistiset järjestöt oli 1930-luvun Suomessa kriminalisoitu. Kun kommunisteilla ei ollut mahdollisuuksia poliittiseen ja ammattiyhdistystoimintaan, puhekuorot ja harrastajateatterit vetivät paljon jäseniä ja tarjosivat verraten vapaan mahdollisuuden seurustella, vaihtaa mielipiteitä ja luoda kontakteja (Vilenius 1971, 110; Pajunen 1976, 21-22).

Elokuussa 1934 Tulenkantajat-lehti kääntyi avoimesti Helsingin työväen näytelmäseurojen puoleen, joilta toivoi terävämpää ohjelmistoa. Samalla "tulenkantajien kirjailijat ja teatterintuntijat" tarjoutuivat kehittämään "jonkin näistä vakituiseksi työväenteatteriksi". ("Kansanteatterin suhde sosiaalisiin kysymyksiin", 1934.) Nyt Työväen Näyttämön työläisnäyttelijät esittivät Tulenkantajien seuralle yhteistyötä, ja teatterille muotoiltiin kansainvälisten esikuvien mukaan poliittisen "proletaariteatterin" mukainen profiili. Tulen-

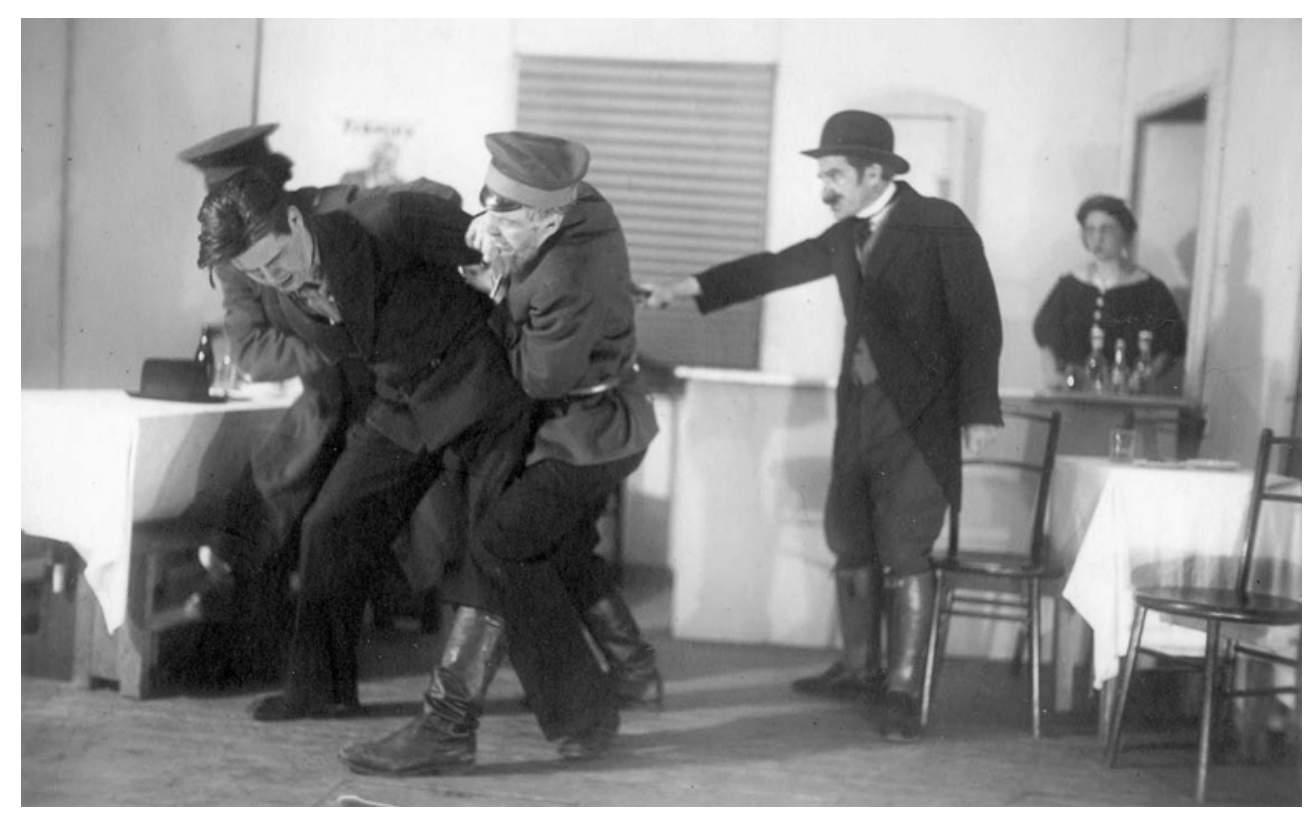

Varastetun kuoleman statistit esiintyivät samankaltaisissa tehtävissä Työväen Näyttämöllä. Santarmiasiamies (Ludvig Korpi) on vangituttanut Aatos Konstin esittämän aktivistin Ere Kolun historiallisessa näytelmässä Voittajat maaliskuussa 1938.

Kuva: Kansan Arkisto. 
kantajain seuran jäsenet Erkki Valan ja toimittaja Helmer Adlerin johdolla miehittivät teatterin johtokunnan, ja Tapio Tapiovaara antautui teatterin lavastajaksi. Ohjaajaksi saatiin lokakuussa 1934 houkuteltua Nyrki Tapiovaara (Vala 1934), jonka johdolla valmistui kaksi tosipohjaista julistavaa amerikkalaista oikeussalidraamaa, ja teatterista tuli puheenaihe. Etsivän keskuspoliisin silmissä muiden tulenkantajien tavoin myös Nyrki Tapiovaara leimattiin äärivasemmistolaiseksi, ja hänestä alettiin kerätä tietoja (Nyrki Tapiovaaran mappi, EK-Valpo, KA). Poliittisia epäluuloja Etsivän keskuspoliisin piirissä olivat omiaan lisäämään tiedot Neuvostoliiton kansainvälisen yhteistyöjärjestön Kominternin 1934 omaksumasta kansanrintamapolitiikasta, jonka mukaisesti kommunistit kaikkialla maailmassa kehotettiin kokoamaan fasisminvastaiset voimat yhteiseen vastarintaan. Neuvostoliitossa toimiva Suomen Kommunistinen puolue tuki taloudellisesti vasemmistoälymystön lehtiä.

Erkki Valan Tulenkantajat-lehti antautui yhteiskunnalliseen kamppailuun fasismin- ja sodanvastaisin tunnuksin ja sai useita painokanteita. Kamppailu oli kiivaimmillaan vuosina 1934-1935, jolloin myös Nyrki Tapiovaara osallistui siihen Työväen Näyttämön ohjauksillaan. Eräs kohokohta koettiin keväällä 1935, kun teatteri esitti vastavalmistuneen Kirjatyöntekijäin talon näyttämöllä Elmer Ricen natsien Leipzigin näytösoikeudenkäyntejä verhotusti kuvaavan oikeussalidraaman Tuomion päivä. Samalla varoiteltiin suomalaisen yhteiskunnan uhkaavasta kehityskulusta. Esitystä avusti mielenosoituksellisesti useita vasemmistolaisen ja vapaamielisen sivistyneistön edustajia - myös Matti Kurjensaari edistyspuolueen piiristä - ja sen yhteydessä koottiin jäseniä eri kansalaispiirejä yhdistäneeseen Ihmisoikeuksien liittoon.

Tulenkantajat-lehti vaikutti Kivimäen hallituksen kaatumiseen syksyllä 1936 julkistamalla haltuunsa saaman Etsivän keskuspoliisin salaisen muistion, jossa kansalaisoikeustaisteluun tavalla tai toisella osallistuneita kansanedustajia ja kulttuurihenkilöitä syyllistettiin arveluttavasta valtionvastaisesta vehkeilystä. Keväällä 1937 muodostettiin Cajanderin punamultahallitus, jossa myös sosialidemokraatit olivat edustettuina. Oikeistoradikaalien vaikutus väheni, mutta myös sosialidemokraattien vasemmistolainen oppositio, mukaan lukien akateemiset sosialistit ja Erkki Vala, erotettiin puolueesta ja marginalisoitiin. (Soikkanen 1975, 582.)

Tässä yhteydessä on todettava, että Tapiovaaran veljeksistä Tapio kiinnittyi vasemmistolaiseen liikkeeseen ja Työväen Näyttämöön tiiviimmin kuin Nyrki, jolle keskeinen viiteryhmä oli Tulenkantajain seura. Nyrki Tapiovaara johti näyttämöä vain yhden vuoden ja ohjasi näyttämölle kaikkiaan neljä näytelmää, joista kolme kaudella 1934-1935 ja neljännen kevättalvella 1937. Hänen poliittista aktivismiaan liioitellaan edelleen ilmeisesti Etsivän keskuspoliisin arkiston johdattamana. Esimerkiksi Lauri Piispa $(2017,13)$ kirjoittaa, että Nyrki Tapiovaara oli avoimesti vasemmistolainen, "kuului 30-luvun vasemmistoradikaalien ytimeen ja Kiila-ryhmän perustajiin". Tosiasiallisesti hän ei lainkaan kuulunut Akateemiseen Sosialistiseuraan, joka kokosi ajan radikaalin vasemmistolaisen älymystön, eikä vasemmistolaisten kirjailijoiden Kiilaryhmään, saati noiden ryhmien ytimeen tai perustajiin. Tapiovaaran poliittisesti julistavan taiteen vaihe ajoittuu Työväen Näyttämön vuosiin 1934-1935, jolloin hän kansalaisoikeustaisteluun liittyvien ohjaustöidensä lisäksi eräässä kirjoituksessaan käsitteli myönteiseen sävyyn paatoksellista ja vitaalista työväenteatteriestetiikkaa (Tapiovaara 1935). Nyrki Tapiovaaran mielenkiinto suuntautui vuosina 1935-1936 ennen muuta elokuvakerho Projektioon, joka kokosi kansainvälisesti suuntautuneita modernisteja (Mickwitz 1995). 
Vaikka ajan proletaarisessa estetiikassa suosittiin paatoksellisia puhekuoroja, teatteriohjaajana Tapiovaara pyrki pelkistämään, karsimaan maneereja ja tavoitteli luonnonmukaista näyttelijänilmaisua. Osittain tämä lienee johtunut jo siitä, että hän työskenteli enimmäkseen harrastajien parissa. Alkuvuodesta 1937 hän ohjasi Työväen Näyttämölle Clifford Odetsin vaimean keskustelunäytelmän Kadotettu paratiisi. Kriitikko Viljo Kajavan (1937) mukaan Tapiovaaran hillitty ohjaus karttoi ulkonaisia tehokeinoja. Syksyllä 1937 Tapiovaara debytoi ammattiteatterin ohjaajana Helsingin Kansanteatterissa. Irwin Shaw'n sodanvastainen julistusnäy telmä Me emme tahdo kuolla herätti torjuntaa oikeistolaisissa piireissä ja joutui teatterin sisäisen sensuurin kouriin (Koski 1987, 101-102). Kriitikko Katri Vala (1937) luonnehti Tapiovaaran ohjausta hyvin hillityksi: "Ei mitään turhaa pateettisuutta, ei tarpeettomia korostuksia."

Vilkkaan Nyrki Tapiovaaran henkilö yhdisti 1930-luvun liberaaliin ja sosialistiseen leiriin kuulunutta nuorta, kansainvälisesti suuntautunutta kulttuuriälymystöä. Hänen laajaan ystäväpiiriinsä lukeutui niin vaaleanpunaisia modernistitaiteilijoita kuin tulipunaisia työläiskommunistejakin. Varastetun kuoleman analyysin kannalta on olennaista, että Tapiovaara oli taiteellisella toiminnallaan aktivistisesti osallistunut oikeusvaltion puolustamiseen. Hän oli läheltä todistanut, miten radikalisoituneet sivistyneistön kasvatit, työläistaustaiset intellektuellit ja jyrkän siiven vasemmistolaiset työläiset tekivät yhteistyötä kulttuurin saralla sekä maanalaisessa poliittisessa toiminnassa, ja miten Etsivä keskuspoliisi pyrki seuraamaan tätä toimintaa.

\section{Näyttelijöitä ja "tyyppejä"}

Varastetun kuoleman alkuteksteissä lukee kaikkiaan kuudentoista näyttelijän nimet ilman viittausta roolihenkilöön. Elonet-tietokannassa on lisäksi mainittu yhdeksän näyttelijän nimet ja myös roolit on yhtä lukuun ottamatta ilmoitettu. Sivustolla ei ole ilmaistu, mistä tiedot ovat peräisin; en ole onnistunut varmentamaan Suomen kansallisfilmografiassa (1995) mainitun Ilmari Paukun esiintymistä elokuvassa. (Elonet-tietokanta, "Varastettu kuolema".)

Elokuvan julkaisemisen aikaan vuonna 1938 ilmestyneissä lehtijutuissa todettiin, että Tapiovaara oli halunnut käyttää uusia kasvoja ja harrastajia, etsinyt "tyyppejä", jotka soveltuivat elokuvaan sellaisinaan, omana itsenään. Kuvauksia seurannut Lyyli Ollila esitteli elokuvaa: "Näyttelijöinä on sekä uusia löytöjä että vanhoja tekijöitä, ohjaaja vastasi tiedusteluumme. Miespääosan esittäjä Ilmari Mänty ei ainakaan ole ammattilainen, mutta sopii tyyppinä hyvin osaansa, sillä hänellä on kultivoitunut ulkomuoto ja synnynnäisen herrasmiehen esiintymistavat..." (Ollila 1938, 32.)

Ei tietenkään pidä aliarvioida käytännön tekijöiden merkitystä. Erik Blomberg kertoi myöhemmin, miten tekijät pyysivät arkunkantajiksi omia kavereitaan, kuten käsikirjoittaja Matti Kurjensaaren ja lavastaja Ilmari Tapiovaaran. Työryhmän muutkin jäsenet vilahtelevat elokuvassa: Blomberg itse puotipuksuna, Tapiovaara junan lähettäjänä ja "meidän timpurimme Karl-Johan [Carl Johan Lindström] näytteli kaikkiaan jotain kymmenkunta osaa, milloin takaa, milloin edestä, ajeli rattaita..." (sit. von Bagh 1980, 17). Erityisen suuri merkitys Blombergin mukaan oli "Kirjan talolla" toimivan Työväen Näyttämön henkilökunnalla: "Katsos Tapiovaarahan oli toiminut teatteriohjaajana Kirjan näyttämöllä ${ }^{1}$ ja hänellä oli sieltä tuttu puoliamatööriporukka mukanaan, joilla miehitettiin kaikki sivuroolit." (sit. von Bagh 1980, 17.)
1 Vuoden 1980 haastattelussa Blomberg puhuu Kirjan näyttämöstä, koska tuolloin Kirjatyöntekijän talolla toiminut Ryhmäteatteri oli omaksunut itselleen tuon nimen. Väärinkäsitysten välttämiseksi on todettava, että samalla talolla toimi myös 1930-luvun lopulla Kirjan Näyttämö -niminen kirjatyöntekijöiden aloitteleva harrastajateatteri. Se jakoi esitystilan Työväen Näyttämön kanssa, mutta elokuvan kanssa sillä ei näytä olleen mitään tekemistä. 
Kaiken kaikkiaan olen tunnistanut Varastetussa kuolemassa neljätoista Työväen Näyttämön jäsentä, ja uskon heitä käytetyn elokuvassa enemmänkin - muutamaa hahmoa en ole onnistunut tekoparran takaa varmuudella nimeämään.

Nyrki Tapiovaaralle oli luontevaa tukeutua Työväen Näyttämön henkilökuntaan, kun hän etsi Helsingissä kuvattavaan matalan budjetin elokuvaansa näyttelijöitä ja avustajia. Kyse oli hänen (entisestä) "omasta" harrastajateatteristaan, jonka näyttelijävoimat olivat keskenään tuttuja ja auliita auttamaan häntä ja jonka johtokunnan puheenjohtajana toimi hänen veljensä Tapio Tapiovaara.

Samalla on olennaista havaita, että Nyrki Tapiovaara haki rooleihin osuvia "tyyppejä", joiden olemus sellaisenaan sopi elokuvaan. Heiltä odotettiin luontevaa läsnäoloa, olemaan esiintymättä. Tämä vastaa Tapiovaaran pyrkimyksiä teatteriohjaajana. Tapiovaara pohti myös artikkeleissaan elokuva- ja teatterinäyttelemisen suhdetta sekä harrastajien ja ammattilaisten eroja. Vuonna 1937 Tapiovaara kirjoitti, että harrastajat sopivat ilmaisemaan luonnollisia tyyppejään sivurooleissa, mutta vaativampaan luonteenkuvaukseen tarvittiin oikeita näyttelijöitä. Ohjaaja oli onnistunut, kun edellisiä ei erottanut jälkimmäisistä. Elokuvassa ei pitänyt näytellä, ainoastaan toimia: "Tyyppiä ei filmissä luoda pääasiassa naamiolla, tyylitellyillä liikkeillä ja muutetulla ääntämisellä, vaan ennen kaikkea osoittamalla, miten kuvattava käyttäytyy eri tilanteissa." (Tapiovaara 1937; Toiviainen 1986, 77-78.)

Fyysisen olemuksen lisäksi näyttelijöiden siviiliroolilla - taustalla tai henkilöhistorialla - oli merkitystä roolivalinnassa. Useassa tapauksessa viittaukset esiintyjän siviilirooliin näyttävät saaneen tilaa elokuvassa. Vaikka kyse on pienistä yksityiskohdista, ne toistuvat pitkin elokuvaa. Nähdäkseni kyse ei ole sisäpiirivitseistä, vaan ohjelmallisesta otteesta. Tunnistaminen tuo elokuvaan ironisen tunnelman ja ruokkii katsojaa irrottautumaan historialliseen tarinaan eläytymisestä osoittamalla yllättäviä, usein nurinkurisesti kuvattuja yhtymäkohtia elokuvan tekoajan yhteiskunnalliseen todellisuuteen.

Varastetun kuoleman pääosissa esiintyivät Tuulikki Paananen, Ilmari Mänty ja Santeri Karilo. Näytelmän konnaa Jonni Claessonia esittävä Karilo (1908-1959) oli "oikea näyttelijä", joka oli Viipurin Kaupunginteatterin jaksonsa jälkeen johtanut Simpeleen Työväennäyttämöä ja työskennellyt Turun Työväenteatterissa. Hänen menestyksekäs filmiuransa oli ehtinyt käynnistyä. Manjaa esitti amerikansuomalainen Tuulikki Paananen (1915-1974), jolla oli tanssitaustaa ja aikaisempi roolityö Tapiovaaran Juhassa (1937).

Ilmari Mänty oli salanimi, jonka suojissa näytteli nuori ulkoministeriön virkamies Ralph Enckell (1913-2001). Enckell on kertonut esiintyneensä ranskankielisen harrastajateatterin näytännöissä Kansallisteatterissa, jolloin teatterinjohtaja Eino Kalima olisi suositellut häntä elokuvantekijöille, ja hän oli taipunut Tapiovaaran maaniteltua häntä koekuvauksiin (Virkkunen 1980, 12). Erik Blomberg puolestaan kertoo asian hieman toisin: "Satuimme näkemään esityksen... Ja sitä paitsi hänhän oli hieman Eugen Schaumanin näköinen. Herraskakarana hän sopi tähän rooliin erinomaisesti sellaisenaan, tyyppinä." (sit. von Bagh 1980, 16). Enckellin isä oli entinen ministerivaltiosihteeri ja ulkoministeri Carl Enckell, joka elokuvan tekemisen aikaan toimi vakuutuslaitoksen johtajana. Schild tin novellin vaatimattomasta perhetaustasta ponnistanut lakitieteen ylioppilas vaihtui elokuvassa "herraskakaraksi", vauraan perheen pojaksi, jonka isältä Claesson pyrkii kiristämään rahoja.

Sivuosiin oli kiinnitetty kolme pitkän linjan naisnäyttelijää, joita ei juuri ollut nähty filmiosissa: 1880-luvulla syntyneet Annie Mörk (1887-1959), Bertha 
Lindberg (1882-1970) ja Hertta Jack-Leistén (1882-1968). Näistä Lindberg pääsi elokuvassa käyttämään kielitaitoaan; hän hallitsi viipurilaisen koulutaustansa ansiosta ruotsin ja venäjän. Vanginvartijana esiintyy näyttelijä Jalmari Parikka (1891-1959), ilmeisesti lapsuksen vuoksi nimellä "Ilmari Parikka". Parikka oli tehnyt 1910-luvulta alkaen pitkän päivätyön etupäässä työväenteattereiden johtajana eri puolilla maata. Hän kuului niihin harvoihin ammattinäyttelijöihin, jotka eivät peitelleet punaista taustaansa: vuonna 1938 tämä entinen punavanki julkaisi muistelmansa toiminnastaan sisällissodassa muun muassa punaisen armeijan rintamapäällikkönä.

Muilta osin Varastetun kuoleman kiinnityksissä turvauduttiin rutinoituneiden harrastajanäyttelijöiden voimiin. Tuulikki Paananen kertoi Suomen Kinolehdelle, miten antaumukselliset sivuosien näyttelijät ja statistit aiheuttivat tähtiroolin esittäjälle itsetunto-ongelmia:

- - jokainen statisti oli siinä määrin paikalleen osuva ja verraton, että ihan hirvitti. Niin, ja hehän olivat luonnontyyppejä, jotka kelpasivat kameran eteen sellaisinaan, ja minua sai ennen joka filmausta parannella kaksi tuntia. - Miten monta tuntia herrat Blomberg ja Tapiovaara ovat käyttäneet näiden tyyppien etsimiseen, ei ole tiedossani, tiedän vain sen, ettei sellaisia ole joka oksalla, eikä joka toisellakaan. (sit. "Varastettu kuolema purkeissa" 1938.)

Työväennäyttämöiden juurevia tyyppejä edustivat Parikan lisäksi Aku Peltonen (1886-1954) ja Lida Salin (s. 1885). Peltonen oli Tapiovaaran kotikaupungin Hämeenlinnan Työväennäyttämön tervaskanto, joka saa ruumishuoneen vartijana lausua repliikin: "Ne muut vain käyvät täällä, minä jään." Salin oli puolestaan pikkutytöstä saakka näytellyt Sörnäisten työväenyhdistyksen näytelmäseurassa (myöhemmin Helsingin Työväenteatteri). Elokuvassa Salin esittää junasta myöhästyvää naista sekä muuttavaa naista. Muuttokohtauksen toinen, ruukkukasvua kantava nainen on Maija Nuutinen Työväen Näyttämön henkilökunnasta.

Ystävällisenä räätälinä esiintyvä sosialidemokraattisen Elanto-lehden toimittaja Eino H. Ahti esiintyi elokuvassa taiteilijanimellään Gabriel Tossu, jolla hänet tunnettiin entisenä kuplettilaulajana, pakinoijana ja kisällilaulujen laatijana. Räätälin ovessa on näyttelijän siviilipuoleen viittaava värssy: "Jos sä hankit kengät somat / niin on mieles huolettomat". Tossu luonnehti kuvauskokemuksiaan tuoreeltaan lehtipakinassa. Uuvuttavissa ulkokuvauksissa järjestäjillä oli työ saada satalukuiset uteliaat sivustakatsojat pysyttelemään kuvan ulkopuolella ja äänettöminä. Ullakkostudioon sisustettuun suutarinverstaaseen oli aikaa tutustua ennen perinpohjaisia harjoituksia ja lopullisia ottoja. Ylinäyttelemisen Tapiovaara, "ilmeetön ja harvasanainen ohjaaja, jonka jokainen lause sisälsi kohteliaan käskyn", karsi armotta pois: "Ei saa innostua liikaa, sillä nykyaikaisessa äänielokuvassa ei leikitä pyöriväsiipistä tuulimyllyä. Kohtaus, mikä alussa on sujunut hyvin, voidaan keskeyttää yhden ainoan tarpeettoman kädenliikkeen tai teennäisen ilmeen vuoksi." (Tossu 1938, 194.) Tossun mukaan ilmaisun karsiminen saattoi johtaa liialliseen eleettömyyteen: "On kuin ateljeen ilmassa huokuisi kehoitus: 'Ole luonnollinen, älä näyttele!' Ja se tekee näyttelijästä luonnollisen, ehkä jossain tapauksessa suorastaan välinpitämättömän, mikä tietystikin on yhtä suuri vika kuin ajattelematon hosuminenkin." (Tossu 1938, 195.)

Erityisen mielenkiintoista on tarkastella, keitä ohjaaja Tapiovaara valikoi kahden vastapuolen, aktivistien ja esivallan, rooleihin. 


\section{Aktivistien sekalainen seurakunta}

Varastetussa kuolemassa esiintyy kuusi Robertin aktivistiystävää, joista neljällä on vuorosanoja. Nähdäkseni Kinisjärvi, Rossi ja Kejonen $(1979,34)$ osuvat harhaan luonnehtiessaan elokuvan aktivistijoukkoa: "Varastetun kuoleman vallankumoukselliset eivät edusta proletariaattia vaan ruotsinkielistä syntyperää olevaa yläluokkaa, eikä ryhmällä ole kontakteja kansan syviin riveihin." Päinvastoin elokuvan aktivistit on kuvattu sosiaaliselta taustaltaan sekalaiseksi joukoksi, joita yhdistää toiminta maanalaisessa liikkeessä. Se, että heillä on ruotsinkielisiä sukunimiä, ei tee heistä säätyläisiä eikä ruotsinkielisiä. Heidän yhteinen kielensähän on suomi, ei ruotsi tai venäjä, joita elokuvassa myös puhutaan. Ruotsinkieliseksi ja yläluokkaiseksi kuvataan lähinnä Robert, jonka tilavan ja aistikkaasti sisustetun asunnon vintillä aktivistien kirjapaino toimii. Kohtauksessa, jossa aktivistit sonnustautuvat ruumissaattoa varten hännystakkeihin, alleviivataan muutamien aktivistien tottumattomuutta säätyläisasuihin. Heidän puhetavoissaan ja korostuksissaan on eroja: Robert murtaa ruotsiin päin, toiset puhuvat kirjakieltä, kolmannet katupoikanuotilla. Tämä kuuluu myös dialogin tasolla, esimerkiksi kun Paavo Kuoppalan esittämä aktivisti tokaisee: "Tulkaa pojat joku laittaa tää simpsetti mun kaulaan. Mun kädet on luotu suurempia töitä varten."

Elokuvan alkuteksteissä on nimetty Atos [po. Aatos] Konst, Viljo Kervinen, Paavo Kuoppala, Yrjö Salminen, jotka myös Suomen kansallisfilmografia mainitsee Robertin tovereiksi. Näistä kolme ensin mainittua kuului Työväen Näyttämön henkilökuntaan. Työväen Näyttämön esityskuviin ja käsiohjelmien potrettikuviin vertailemalla varmistuu, että he esittivät puherooleissa Hedmanin lähimpiä aktivistitovereita: Konst silmälasipäistä aktivistia, Kuoppala lyhyttä kiharatukkaista hahmoa ja Kervinen vaaleatukkaista toveria. Kuoppala toimi Suomen kansallisfilmografian mukaan myös elokuvan lavastemiehenä ja kuvausryhmän jäsenenä. On ilmeistä, että neljättä puheroolia, kirjapainon

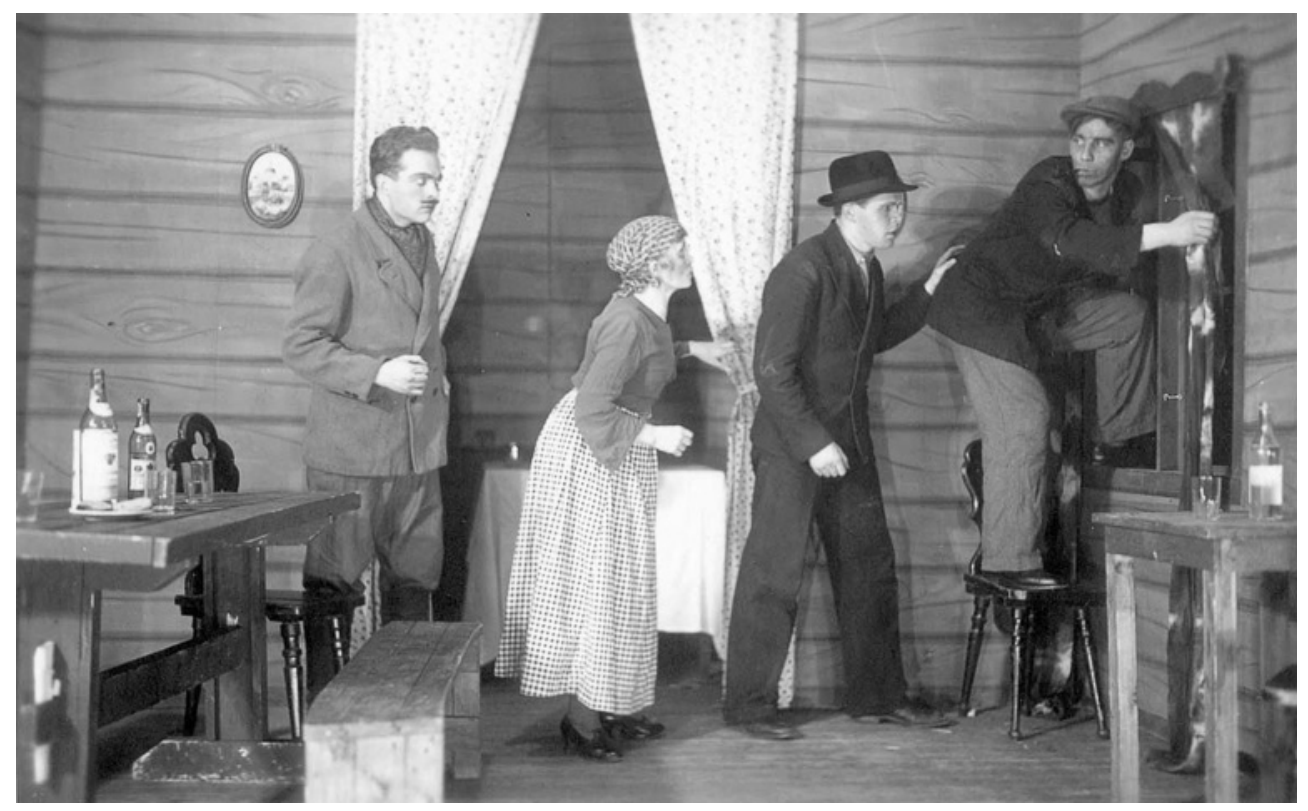

Työväen Näyttämön Viljo Kervinen (vas.), Aatos Konst ja Paavo Kuoppala aktivisteina Ere Kolun näytelmässä Voittajat (1938). Sama kolmikko esiintyi aktivisteina Varastetussa kuolemassa. Kuva: Kansan Arkisto. 
kaljupäistä käyttelijää, esittää Yrjö Salminen - hänen taustaansa en ole onnistunut selvittämään. Sen sijaan teatterin käsiohjelmien ja Etsivän keskuspoliisin arkistokuvien vertailu paljastaa edelleen, että puhumaton tummahiuksinen aktivisti, joka myöhemmässä varjostuskohtauksessa käyttelee rappukäytävässä nyrkkejään, on Työväen Näyttämön henkilökuntaan kuulunut viilari Holger Vigrén (s. 1914). Jäljelle jää hoikka ohutviiksinen aktivistinuorukainen. Hänen esittäjänsä on Arne Runeberg (1912-1979), jonka Elonet-tietokanta mainitsee ainoastaan arkunkantajan roolissa. Hän oli kansallisrunoilija Johan Ludvig ja kuvanveistäjä Walter Runebergin jälkeläinen, myöhempi sosiaaliantropologian tutkija (Gothoni 2006).

Elokuvan seitsemän hengen aktivistijoukko koostuu siis esiintyjistä, jotka eivät olleet ammattinäyttelijöitä vaan Tapiovaaran havittelemia "tyyppejä": he pystyivät ilmentämään elokuvan taustaltaan erilaisia aktivisteja. Kaksi heistä lukeutui ruotsinkieliseen eliittiin, muut olivat työväen riveistä. On toki huomioitava, että Konst, Kervinen ja Kuoppala esiintyivät jo tuolloin suurissa tehtävissä Työväen Näyttämön palkeilla ja pystyivät verraten luontevasti tarvittaessa vaihtamaan rekisteriään. Aktivistien rooli ei ollut heille vieras, päinvastoin. Maaliskuussa 1938, jolloin Varastetun kuoleman kuvaukset alkoivat, Työväen Näyttämöllä tuli näet ensi-iltaan Ere Kolun (oik. Kustaa Liukosen) 1900-luvun alun santarmivaltaa kuvaava näytelmä Voittajat, jossa Konst, Kervinen ja Kuoppala esittivät nimenomaan aktivisteja. (Näytelmän Voittajat käsiohjelma ja esityskuvat, Kansan arkisto.)

\section{Sotilaat, santarmit ja ohranat}

Varastetun kuoleman alkuteksteissä on nimeltä mainittu vain kaksi venäläisen esivallan esittäjää, Kusti Laitinen ja Emil Kokkonen. Elokuvassa Kokkonen esittää humoristisessa kohtauksessa venäläistä sotamiestä, joka tekee innokkaasti tuttavuutta lastenrattaita työntävän Manjan kanssa. Kokkonen oli tullut tunnetuksi Työväen Näyttämöllä erityisesti yhdestä kiitellystä pääroolistaan: hän näytteli lupsakkaa sotamies Shvejkiä syksyllä 1936 Pentti Raunion näyttämösovituksessa. Pasifistisen sotanäytelmän pieni sotamies panee huumorin kapuloita sotakoneiston rattaisiin. (Sinervo 1936.) Tulenkantajat-lehdessä julkaistu Jaroslav Hashekin romaanin suomennoskatkelma oli saanut 1935 kansainvälistä kohtua herättäneen painokanteen, jonka tuomio oli kumoutunut vasta korkeimmassa oikeudessa, joten teoksella oli erityinen symboliarvo kansalaisoikeustaistelun kiistakapulana (Erkki Valan haastattelu 5.11.1973, SKS). Pidän selvänä, että Kokkosen Shvejk-roolityö oli pohjana elokuvan lastenvaunukohtaukselle, jonka humoristisuutta posetiivi ja torvimusiikki erityisesti alleviivaavat.

Alkutekstien lisäksi tietoja elokuvassa esiintyvistä näyttelijöistä paljastuu Etsivän keskuspoliisin arkistosta. Poliisi näet seurasi paitsi Nyrki Tapiovaaraa, myös suurta osaa Työväen Näyttämön jäsenistä. Nyrki Tapiovaaran henkilömapissa EK:n arkistossa on 5.4.1938 päivätty "Toivo Kallion" tiedonanto, jossa kerrotaan Tapiovaaran kuvaavan elokuvaa. Tiedonantajan mukaan elokuvassa esiintyvät Kusti Laitinen (santarmieversti), Emil Inkinen ja Kössi Leino (ohranoita) sekä Pentti Raunio, Ludvig Korpi, Topi Koljonen ja Matti Jalava (sotamiehiä). "Elokuvassa on mm sellainen kohtaus, että konekivääri olisi piilotettuna ruumisarkkuun, mutta kun ohranat avaavat ruumisarkun, niin siellä onkin ruumis", tiesi Kallio. (Toivo Kallion tiedonanto 5.4.1938, 
Nyrki Tapiovaaran mappi, EK-Valpo, Kansallisarkisto.) Tiedonannon ansiosta Etsivälle keskuspoliisille ei jäänyt epäselväksi, että heitä ilkuttiin.

Paitsi että tiedonanto paljastaa sivuosanäyttelijöiden nimiä, se kertoo myös että elokuvantekijöiden joukkoon oli soluttautunut "vasikka", EK:n tiedonantaja. Tuo kaksoisagentti oli santarmieverstin esittäjä Kusti Laitinen (s. 1894), joka lähetti tiedonantoja EK:lle maaliskuusta 1937 kesään 1940 peitenimellä Toivo Kallio. Niinpä hän pystyi nimeämään nimenomaan omissa kohtauksissaan esiintyvät näyttelijät. Kusti Laitinen oli kokenut värikkäitä elämänvaiheita ja tottunut kaksoiselämään. Hän toimi näyttelijänä jo ennen sisällissotaa, jonka jälkeen piilotteli Neuvosto-Venäjällä ja Ruotsissa. Hän palasi Suomeen kadonneen veljensä identiteetillä ja työskenteli muun muassa kiertävänä psykoterapeuttina ennen kuin paljastui ja tuomittiin vankilaan punakapinan aikaisesta toiminnastaan. Vapauduttuaan hän sai 1932 uuden vankeusrangaistuksen kommunistiseen soluun kuulumisesta. Työväen Näyttämöllä Laitiseen suhtauduttiin hivenen epäluuloisesti. Kun hän syksyllä 1937 esitti Työväen Näyttämöllä Shvejkissä menestyksellä ohranan roolia, hänelle ilkuttiin, että hän olisi ottanut roolin vakaumuksesta - häntä näet "todellisuudessakin on pitkät ajat yleisesti pidetty ohranana". Myös johtaja Pentti Raunio oli ottanut hänen kanssaan yhteen ja erottanut tämän henkilökunnasta, mutta teatterin johtokunnan puheenjohtaja Tapio Tapiovaara antoi teatterin ilmoitushankijana toimineelle Laitiselle täyden tukensa. (Kusti Laitisen henkilömappi, EK-Valpo, KA.)

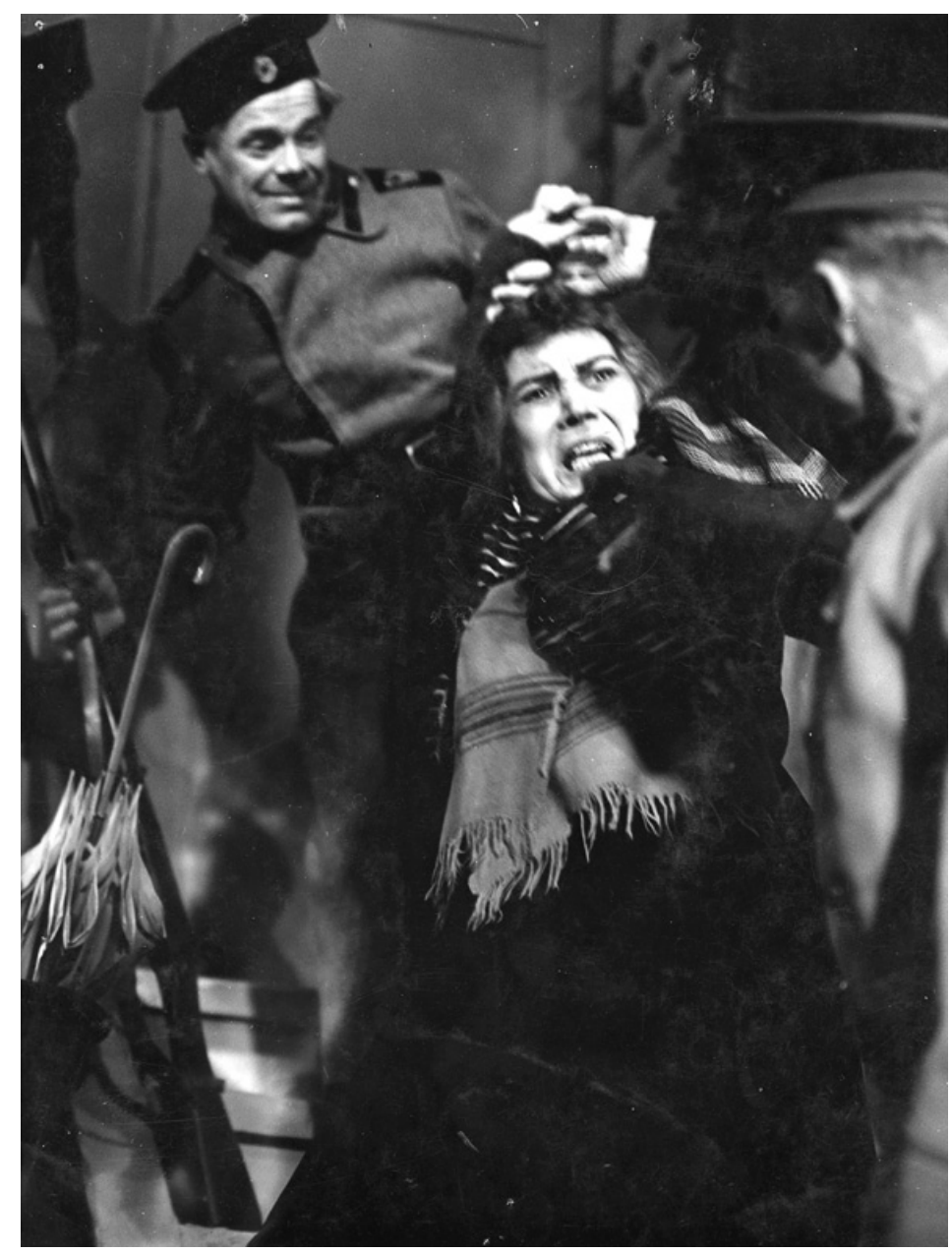

Varastetun kuoleman santarmien, sotilaiden ja ohranan rooleissa esiintyivät Työväen Näyttämön kommunistinäyttelijät. Kuvassa ratsia matami Johanssonin (Annie Mörk) diverssipuotiin, santarmina Matti Jalava. Kuva: KAVI. 
Työväen Näyttämön henkilökunnan valokuvia vertailemalla voi helposti vahvistaa ilmiannon tiedot oikeiksi. Kusti Laitisen tulkitseman monokkeliin pukeutuneen santarmipäällikön johtamaan sotilasosastoon, joka tekee ratsian matami Johanssonin diverssipuotiin, kuuluvat vaalea Pentti Raunio, joka toimi Työväen Näyttämön johtajana ja ohjaajana näytäntövuoden 1937-1938, lyhyt tumma Ludvig Korpi (s. 1891) sekä Matti Jalava, jonka esittämä sotilas sulloo matamin puodissa tavaraa omiin taskuihinsa. Toisessa kohtauksessa Laitisen santarmieversti tunkeutuu Robertin asuntoon kahden siviiliasuisen ohranan kanssa. Heitä esittävät riippuviiksinen Emil Inkinen sekä Kössi Leino. Santarmieverstin kolmas ratsia suuntautuu suutarin verstaaseen, jolloin hänen takanaan portaissa tirskuu vaalean Toivo "Topi" Koljosen esittämä sotamies.

Näiden lisäksi olen voinut tunnistaa elokuvan vankilapakokohtauksen kaksi parrakasta sotilasta, joita esittävät räätäli Ludvig Korpi sekä suutari Iivari Kiviranta, molemmat teatteriryhmän 1920-luvun veteraaneja (samoin kuin Matti Jalava). Heillä oli samankaltaiset tehtävät Työväen Näyttämön kevään 1938 esityksessä Voittajat.

Tunnistamastani neljästätoista Työväen Näyttämön näyttelijästä kuusi oli saanut Etsivän keskuspoliisissa oman mappinsa, koska heidät oli tuomittu kommunisteina. Erityisen vaarallisina tai vaikutusvaltaisina maanalaisen kommunismin levittäjinä pidettiin salaisen poliisin eli ohranan esittäjiä, Leinoa ja Inkistä. Rakennusmies Kössi Leino (1893-1957) oli osallistunut punakapinaan, johtanut sitten maanalaista Punaista rintamamiesjärjestöä ja värvännyt vielä 1937 Suomesta sotilaita Espanjan sisällissotaan. Hän oli istunut vankilassa punakapinan jälkeen kaksi vuotta ja 1930-luvun alussa neljä vuotta. Välirauhan aikana hänet suljettiin turvasäilöön, josta hän vapautui vasta neljän vuoden kuluttua, kun sota oli päättynyt. (Kössi Leinon henkilömappi, EK-Valpo, KA.)

Maalari Emil Inkinen (s. 1894) oli hänkin sisällissodan punaisen puolen veteraaneja - itse asiassa hän tunsi elokuvassa esiintyneen Jalmari Parikan jo sisällissodan ajoilta, jolloin miehet toimivat Enson työväenyhdistyksessä. Inkinen oli kommunistina tuomittu uudestaan 1931 kolmeksi vuodeksi kuritushuoneeseen. Vapauduttuaan hän liittyi Työväen Näyttämön piiriin toimien sen hallinnossa - näyttämöllä Inkinen ei näytä esiintyneen. (Emil Inkisen henkilömappi, EK-Valpo, KA.)

\section{Ironian kaksoisvalotus ja poliittinen elokuva}

Aikaisemmassa tutkimuksessa on korostettu, että Varastetun kuoleman viittaukset oman aikansa maanalaiseen kommunismiin jäävät piiloon. Oma käsitykseni asiasta on päinvastainen. Elokuva kutsuu tulkitsemaan itseään 1930-luvun ajankuvana. Se tekee tämän ironian avulla.

Ironia johtuu kreikan kielen sanasta 'teeskentely'. Marvin Carlson on korostanut, miten ironian kaksoisvalotus tai dialektiikka on teatteriin - ja miksei myös fiktioelokuvaan - olennaisesti liittyvä piirre. Ironisuus liittyy olennaisesti asetelmaan, jossa katsoja seuraa draamaa (tai elokuvaa) tietoisena siitä, että kyseessä on vain illuusio. Katsojan suhtautuminen vaihtelee järjen viileän puntaroinnin ja empaattisen myötäelämisen välillä. Ironia terävöityy, kun katsoja tietää jotakin mitä näytelmän henkilö ei tiedä. (Carlson 2001, 28-29.) Myös Bertolt Brechtin 1930-luvulla muotoilema poliittisen tai eeppisen teatterin teoria rakentui ironian ja dialektiikan hyödyntämiselle ja katsojan empaattisen suhtautumisen rikkomiselle. 
Varastettu kuolema leikittelee useilla kaksoisvalotuksilla. Ennen muuta se rinnastaa 1900-luvun alun sortokauden 1930-luvun poliittisen tilanteen kanssa ja luo henkilökuvaukseen uusia tasoja tarkkaan harkitulla roolituksella.

Elokuvassa sääty- ja kielirajat ylittävä aktivistien piiri päättää koventaa menettelytapaansa ja korvata maanalaisten lehtien painamisen ja levittämisen aseiden hankkimisella. Tämä asetelma vastasi 1900-luvun alkuvuosien aktivistisen vastarintapuolueen tilannetta (vrt. Kujala 1995), mutta samalla se resonoi voimakkaasti elokuvan tekoajan poliittisen tilanteen kanssa.

Kansanrintamapolitiikan ja kansalaisoikeustaistelun nimissä sivistyneistön ja työläisten piirit olivat solidaarisesti yhdistäneet voimansa julkiseen aktivistiseen toimintaan. Espanjan sisällissodan syttyminen puolestaan merkitsi eurooppalaisen vasemmiston, etenkin kommunistien, piirissä entisen pasifistisen asenteen hylkäämistä ja tarttumista aseisiin fasismia vastaan. (Grindon 1994, 30; Koivisto \& Parikka 2015, 8, 19.) Sama käänne näkyi myös Suomessa (Aho 2015), jossa Työväen Näyttämö osallistui Kaisu-Mirjami Rydbergin ja Tapio Tapiovaaran johdolla Espanja-keräyksiin ja vaihtoi sodanvastaisen julistuksen sotaisampaan asenteeseen: teatterin syksyn 1938 ensi-iltoihin kuului Bertolt Brechtin näytelmä Rouva Carrarin kiväärit, jossa liitytään sotaan Espanjan tasavallan puolesta. Myös teatterin kaksi jäsentä oli liittynyt vapaaehtoisina tasavallan joukkoihin. (Pajunen 1976, 23.)

Nyrki Tapiovaaralle oli käytännöllistä tukeutua Työväen Näyttämön henkilökuntaan, jolla kaiken lisäksi oli puvustossaan runsaasti sotilasmantteleita pasifistisen ohjelmistonsa ansiosta. Mutta yhtä tärkeää on huomioida elokuvan poliittisen tulkinnan kannalta sen seikan merkitys, että mainittu teatteriryhmä oli sitoutunut fasisminvastaiseen taisteluun. Työväen Näyttämön henkilökunnan kiinnittäminen avustajaksi vahvisti elokuvan luentaa poliittisena kommenttina kansalaisoikeuksien puolesta valtiollista sortohallintoa vastaan. Erityisen terävästi Tapiovaara rinnasti Venäjän keisarikunnan aikaisen salaisen poliisin ja 1930-luvun Etsivän keskuspoliisin. Roolitus, jossa valtiopetoksen valmistelusta tuomitut, Etsivän keskuspoliisin seuraamat miehet esittävät salaisen poliisin ja sotilaiden rooleja, ironisesti alleviivaa historiallisen ajan yhtymäkohtia elokuvan kuvausaikaan - erityisesti sortovallan osalta. Samalla se kyseenalaistaa esivallan auktoriteettia ja moraalia. Poliisin vainoamat työläisaktivistit pääsivät nyt matkimaan valtiollisen kontrollin edustajia. Kommunisteina tuomitut tai sellaisiksi leimatut työläisnäyttelijät laukoivat ratsiakohtauksissa venäjänkielisiä repliikkejä. Ohranan varjostajat esitetään haudanvakavasti, mutta sotilaiden kohdalla tarjoillaan ilkkuvia karikatyyreja.

Elokuva kutsuu tulkitsemaan itseään myös vasten Nyrki Tapiovaaran omaa henkilöhistoriaa. Tämä tapahtuu myös käsikirjoituksen tasolla. Päähenkilö Robert Hedmanin yhtymäkohtia ohjaaja Tapiovaaraan alleviivataan Manjan ja Robertin ensimmäisessä yhteisessä kohtauksessa Robertin asunnossa. Käy ilmi - aivan kuten Schildtin teoksessa - että Robert lukee lakia. Robertin kotiseutu sen sijaan on vaihdettu. Manja näkee Robertin pöydällä nuoren neidon kuvan, jonka hän "Lihamylly"-novellissa arvaa asun ja kampauksen perusteella tammisaarelaiseksi - mutta elokuvassa paikkakunta on vaihdettu Hämeenlinnaksi Tapiovaaran kotikaupungin mukaan. Tämä ensimmäinen "sisäpiirivitsi" rohkaisee osaltaan havaitsemaan elokuvassa muitakin kommentteja Tapiovaaran ja muiden tekijöiden kokemaan 1930-luvun aikalaistodellisuuteen. Elokuvassa Robert Hedmanin ja toisen aktivistiroolin miehittäminen Ralph Enckellillä ja Arne Runebergillä tukee käsikirjoituksen muutosta, jossa kiristäjä Claesson pyrkii vaurastumaan seikkailevien idealistien varakkaiden vanhempien kustannuksella. 
Itsestään tietoisella roolituksella vahvistettiin myös elokuvan leikkisää ja kokeilevaa otetta: ohjaaja Tapiovaara, tuottaja Blomberg ja käsikirjoittaja Kurjensaari näyttäytyivät pienissä tehtävissä, useiden esiintyjien (Gabriel Tossu, Emil Kokkonen, Aku Peltonen) historian tai siviilitaustan annetaan "kummitella" roolin alta. (Tästä ilmiöstä ks. Carlson 2001, 84-87.)

Leger Grindon on kuvannut, miten historiaan tietoisesti suhtautuvissa elokuvissa tulkitaan avoimen rohkeasti menneisyyttä ja pyritään siten osallistumaan niiden oman tekoajan julkiseen keskusteluun ja mielipiteen muodostamiseen. Mielenkiintoisesti Varastettu kuolema vertautuu Jean Renoirin helmikuussa 1938 valmistuneeseen Ranskan vallankumousta käsittelevään elokuvaan Marseljeesi (La Marseillaise). Grindonin mukaan elokuva pui siinä sivussa myös Ranskan 1930-luvun kansanrintaman ja vuonna 1937 kaatuneen kansanrintamahallituksen vaiheita, mikä ei jäänyt ensi-iltakritiikiltä huomaamatta. (Grindon 1994, 2, 66.)

On vielä aiheellista tarkastella, miten Varastetun kuoleman ensi-iltayleisö koki elokuvan poliittisuuden. Tarkastelu tuottaa laihan saaliin. Samaan tapaan kuin Työväen Näyttämön esitysten kohdalla, pääasiallinen reaktio oli vaikeneminen. Kriitikot kiinnittivät huomiota elokuvan kuvaukseen ja leikkaukseen, sen ranskalaisvaikutteiseen kokeelliseen otteeseen, ylilyövään "taiteellisuuteen". Blombergia ja Tapiovaaraa pidettiin elokuvan lupauksina, joiden työhön kohdistui odotuksia. Lopputulosta pidettiin tässä suhteessa hienoisena pettymyksenä. Ongelmat paikannettiin nimenomaan juonen ja käsikirjoituksen hataruuteen. Elokuvan todellisuuspohjan sijaan korostettiin fantasian ja mielikuvituksen osuutta. Näyttelijöistä huomio keskitettiin uuteen "tähteen", naispääosan esittäjä Tuulikki Paanaseen, sekä sivuosan vivahteikkaasti tulkinneeseen Annie Mörkiin. (Hällström 1938; "Elokuva" 1938; "Kotimainen elokuvatuotanto laajenee yhä" 1938; Suomen kansallisfilmografia 1995, 253-254.)

Elokuvan liittyvässä kirjoittelussa kiinnitettiin huomiota, että se oli miehitetty harrastajanäyttelijöillä tai "tyypeillä". Vaikka elokuvan julkisessa vastaanotossa ei analysoitu roolien miehitystä sen tarkemmin, elokuva tulkittiin ainakin oikeistolaisissa leireissä lähtökohtaisesti poliittisesti. Mioppilaslehti vihjasi tähän suuntaan: "Tämä elokuva on kai laskettava 'kulttuurivasemmistolaistemme' esiinmurroksi" ("Elokuva" 1938). Oikeistoradikaalisen Isänmaallisen Kansanliikkeen äänenkannattaja Ajan Suunta ei peitellyt havaintojaan elokuvasta aktivismin kuvauksena, mutta se kiisti tämän vääränlaisen aktivismin isänmaallisuuden kaataessaan täysilaidallisen elokuvan tekijöiden niskaan:

Elokuvan pitäisi esittää helsinkiläisten aktivistiylioppilaiden toimintaa venäläis-japanilaisen sodan aikana. Kuitenkin on tuon toiminnan pohja, rakkaus isänmaahan ja Suomen kansan vapaudentahto jätetty kokonaan syrjään. Asehankinnoissa puuhaavat nuorukaiset voivat yhtä hyvin olla venäläisiä nihilistejä kuin suomalaisia aktivistejakin - edelliseen viittaavat puheet vallankumouksesta ja tsaarista. Kun elokuvan on ohjannut "tulenkantajana" tunnettu Nyrki Tapiovaara, ymmärtää, mistä aatteellinen onttous johtuu - - suomalainen henki puuttuu. (sit. Suomen kansallisfilmografia 1995, 254-255.)

Se koira älähtää, johon kalikka kalahtaa. Ajan Suunta riitautti Varastetun kuoleman esittämän historiantulkinnan. 1930-luvun kosmopoliittisia kansalaisoikeusaktivisteja ei saanut rinnastaa 1900-luvun alun patrioottisiin aktivisteihin. Vaikka elokuvan poliittisuus tuotiin näin lupaavasti päivänvaloon, julkinen keskustelu aiheesta ei jatkunut. 
Historiankuvan oikaisevaksi puheenvuoroksi muodostui toinen elokuva, Risto Orkon ohjaama Aktivistit, joka valmistui kevääksi 1939. Historialliseen autenttisuuteen pyrkinyt elokuva sisälsi myös ideologisen korjausliikkeen painottaessaan suomalaisten itsenäisyystahtoa ja tehdessään voimakasta pesäeroa venäläisiin. ("Aktivistit" 2017.) Elokuvien keskinäistä jatkumoa alleviivasi, että Tuulikki Paananen sai jälleen esittääkseen kiihkeän slaavilaisen kaunottaren, Katjushkan (Salakka 1992, 33). Historiallisten elokuvien poliittisuus ilmeni myös siinä, miten Paananen leimautui elokuvarooliensa vuoksi. Kun hän juuri talvisodan alla jätti Suomen palatakseen Yhdysvaltoihin, perättömät huhut leimasivat hänet vakoilijaksi. Paananen vastasi huhuihin New Yorkista 6.12.1939 lähetetyllä sähkeellä, jonka Risto Orko välitti julkisuuteen: "Suurenmoista reklaamia Suomen Tuulikki" ("Näyttelijämme nykytehtävissään" 1940, 36; Adler 1940, 44).

\section{Yhteenveto}

Nyrki Tapiovaaran Varastettu kuolema (1938) on historiallisesta aiheestaan huolimatta poliittinen elokuva, 1930-luvun kansalaisoikeusaktivismin ja suomalaisen kansanrintamapolitiikan ilmaus. Toisin kuin aikaisemmassa tutkimusperinteessä on arvioitu, elokuva kutsui tulkitsemaan itseään 1930-luvun ajankuvana ja vasten Nyrki Tapiovaaran omaa henkilöhistoriaa. Poliittista tulkintaa vahvistettiin roolien tietoisella miehittämisellä sekä käsikirjoituksen muutosten kautta. Käsikirjoituksesta vastasivat Tapiovaara ja Matti Kurjensaari, roolitus tapahtui Tapiovaaran ja tuottaja-kuvaaja Erik Blombergin johdolla.

Varastettu kuolema rinnastaa 1900-luvun alun Venäjän sortovaltaa vastustaneet aktivistit 1930-luvun kansalaisoikeusaktivistien kanssa. Molemmissa tapauksissa aktivistinen toiminta veti eliitin ja työläisten piirejä yhteistyöhön. Erityisen terävästi elokuva rinnastaa 1900-luvun alussa toimineen Venäjän salaisen poliisin, ohranan, 1930-luvun Etsivän keskuspoliisin kanssa. Elokuvan nuorten aktivistien ihanteellinen toiminta ja valtiollista kontrollia edustavan ohranan varjostukset ja ratsiat vastaavat 1930-luvun tilannetta, jossa Etsivä keskuspoliisi seurasi herkeämättä kommunistien ja heidän hallussaan olevien kirjapainovälineiden ja kirjoituskoneiden liikkeitä.

Nyrki Tapiovaaran henkilö yhdisti 1930-luvun liberaalia ja vasemmistolaista nuorta älymystöä sekä työläiskommunisteja. Nuoren vasemmistoälymystön ja työläisten keskeinen yhteinen toiminta-alusta oli Työväen Näyttämö -niminen harrastajateatteri, jota Etsivä keskuspoliisi piti kommunistien pesäpaikkana. Teatteri pyrki kehittämään kokeellista poliittista "proletaariteatteria" kansainvälisten esikuvien mukaan. Kun Tapiovaara ohjasi teatterille kautena 1934-1935 oikeusvaltiota puolustavia julistavia näytelmiä, Etsivä keskuspoliisi leimasi myös hänet äärivasemmistolaiseksi ja ryhtyi seuraamaan hänen liikkeitään. Etsivän keskuspoliisin menettely sai osakseen laajaa arvostelua, kun sen salaiset kansanrintamamuistiot vuosivat julkisuuteen syksyllä 1936. Skandaali, jossa kansalaisoikeustaisteluun tavalla tai toisella osallistuneita kansanedustajia ja kulttuurihenkilöitä syyllistettiin arveluttavasta valtionvastaisesta vehkeilystä, vauhditti Kivimäen hallituksen eroa.

Nyrki Tapiovaara haki rooleihin luonnollisia "tyyppejä", joiden olemuksella ja siviiliroolilla - taustalla tai henkilöhistorialla - oli merkitystä roolivalinnassa. Useiden esiintyjien historian tai siviilitaustan annettiin "kummitella" roolin alta. 
Toisin kuin aikaisemmassa tutkimuksessa on tulkittu, Varastetun kuoleman aktivistit on kuvattu sosiaaliselta taustaltaan sekalaiseksi joukoksi, joita yhdistää ihanteellinen toiminta maanalaisessa liikkeessä. Elokuvan seitsemän hengen aktivistijoukko koostuu esiintyjistä, jotka eivät olleet ammattinäyttelijöitä vaan Tapiovaaran havittelemia "tyyppejä": he pystyivät ilmentämään elokuvan taustaltaan erilaisia aktivisteja. Kaksi heistä lukeutui ruotsinkieliseen eliittiin, muut olivat työväen riveistä. Tätä alleviivatakseen Tapiovaara miehitti osan rooleista Työväen Näyttämön harrastajanäyttelijöillä, jotka olivat esittäneet aktivisteja myös teatterin lavalla, sekä osan ruotsinkieliseen yläsäätyyn kuuluvilla nuorukaisilla.

Varastetussa kuolemassa esiintyi ainakin neljätoista Työväen Näyttämön jäsentä, joista kuusi oli tuomittu kommunisteina. Työväen Näyttämön henkilökunnan kiinnittäminen avustajaksi vahvisti elokuvan luentaa poliittisena kommenttina kansalaisoikeuksien puolesta valtiollista sortohallintoa vastaan. Tapiovaaralle oli luontevaa tukeutua "oman" teatterin henkilökuntaan, kun hän etsi Helsingissä kuvattavaan matalan budjetin elokuvaansa näyttelijöitä ja avustajia. Tapiovaaran ratkaisu miehittää elokuvan santarmien ja ohranan roolit tuomituilla kommunisteilla erityisesti palveli rinnastamaan elokuvan salaisen poliisin ja 1930-luvun Etsivän keskuspoliisin.

Varastettu kuolema hyödyntää ironiaa ja leikittelee useilla kaksoisvalotuksilla. Ennen muuta se rinnastaa 1900-luvun alun sortokauden 1930-luvun poliittisen tilanteen kanssa ja luo henkilökuvaukseen uusia tasoja tarkkaan harkitulla roolituksella.

Roolitus, jossa valtiopetoksen valmistelusta tuomitut, Etsivän keskuspoliisin seuraamat miehet esittävät salaisen poliisin ja sotilaiden rooleja, alleviivasi ironisesti historiallisen ajan yhtymäkohtia elokuvan kuvausaikaan - erityisesti sortovallan osalta. Poliisin vainoamat työläisaktivistit pääsivät nyt matkimaan valtiollisen kontrollin edustajia. Kommunisteina tuomitut tai sellaisiksi leimatut työläisnäyttelijät laukoivat ratsiakohtauksissa venäjänkielisiä repliikkejä. Ohranan varjostajat esitetään haudanvakavasti, mutta sotilaiden kohdalla tarjoillaan ilkkuvia karikatyyreja.

Tunnistaminen tuo elokuvaan ironisen ja hetkittäin karnevalistisen tunnelman ja ruokkii katsojaa irrottautumaan historialliseen tarinaan eläytymisestä osoittamalla yllättäviä, usein nurinkurisesti kuvattuja yhtymäkohtia elokuvan tekoajan yhteiskunnalliseen todellisuuteen.

Itsestään tietoisella roolituksella vahvistettiin myös elokuvan leikkisää ja kokeilevaa otetta: myös ohjaaja Tapiovaara, tuottaja Blomberg ja käsikirjoittaja Kurjensaari näyttäytyivät pienissä tehtävissä. Elokuvan vastaanotossa kiinnitettiin huomiota kokeilevaan kuvaukseen ja leikkaukseen, jossa kuvallinen briljeeraus ja vitsikkyys tallasi alleen juonen. Elokuvan sisältämän aikalaiskommentaarin suhteen vastaanoton pääasiallinen reaktio oli vaikeneminen. Elokuva kuitenkin ymmärrettiin "kulttuurivasemmiston" esiintulona, ja Etsivä keskuspoliisi tiesi tulleensa pilkan kohteeksi. Elokuvan politisoi avoimesti oikeistoradikaalinen Ajan Suunta. Lehti polemisoi voimakkaasti elokuvan tarjoaman kuvan aktivismista, rinnasti sen venäläiseen nihilismiin ja pyrki kiistämään ohjaaja Tapiovaaran isänmaallisuuden. 


\section{Lähteet}

Elonet-tietokanta

"Aktivistit" (2017), <http://www.elonet.fi/fi/elokuva/107842> (linkki tarkistettu 27.6.2017).

"Varastettu kuolema" (2017), <www.elonet.fi/fi/elokuva/107837> (linkki tarkistettu 26.4.2017).

Kansallinen Audiovisuaalinen Arkisto (KAVI)

Elokuva Varastettu kuolema (1938)

Kansallisarkisto (KA)

Etsivä keskuspoliisin - Valtiollisen poliisin arkisto (EK-Valpo): henkilömapit (Emil Inki nen, Ludvig Korpi, Kusti Laitinen, Kössi Leino, Nyrki Tapiovaara, Erkki Vala, Holger Vigrén, Hulda Virtanen)

Kansan Arkisto

Työväen Näyttämön arkisto: pöytäkirjat, käsiohjelmat ja valokuvat

Tapio Tapiovaaran arkisto: Työväen Näyttämön käsiohjelmat

Suomalaisen Kirjallisuuden Seuran Kirjallisuusarkisto (SKS)

Erkki Valan arkisto

\section{Kirjallisuus}

Adler, Helmer (1940) "Nyrki Tapiovaara". Kiilan albumi 3, 36-46.

Aho, Mikko (2015) "Espanjan asia on meidän: Suomen vasemmistososialistien ja kommunistien propaganda ja toiminta Espanjan tasavallan puolesta". Teoksessa Hanne Koivisto \& Raimo Parikka (toim.) No pasarán! Espanjan sisällissodan kulttuurihistoriaa. Helsinki: Työväen historian ja perinteen tutkimuksen seura, 361-417.

Bagh, Peter von (1980) "Kuvaajan matka menneeseen". Filmihullu 8, 8-21.

Carlson, Marvin (2001) The Haunted Stage. The Theatre as Memory Machine. Ann Arbor: The University of Michigan Press.

"Elokuva" (1938) Mioppilaslehti 9, 212.

Gothoni, René (2006) “Runeberg, Arne”. Suomen kansallisbiografia 8. Helsinki: SKS, 401-403.

Grindon, Leger (1994) Shadows on the Past. Studies in the Historical Fiction Film. Philadelphia: Temple University Press.

Hupaniittu, Outi \& Piispa, Lauri (2015) "Hella Wuolijoki ja neuvostoelokuva 1929-1930". Lähikuva 3, 7-29.

Hällström, Raoul af (1938) "Kuvien valohämyä”. Elokuva-aitta 18, 387-379.

Kajava, Viljo (1937) "Työväen Näyttämö". Tulenkantajat 3.4.1937, 15.

"Kansanteatterin suhde sosiaalisiin kysymyksiin" (1934) Tulenkantajat 18.8.1934.

Kinisjärvi, Raimo (1979) "Nyrki Tapiovaara - Suuri suomalainen kulttuuripoliitikko ja elokuvateoreetikko". Teoksessa Jukka Rossi (toim.) Vuosikirja 2. Oulu: Oulun elokuvakeskus, 10-29.

Kinisjärvi, Raimo; Rossi, Jukka \& Kejonen, Pentti (1979) "Varastettu kuolema - itsetietoisen ohjaajan vapautunutta ilmaisua". Teoksessa Jukka Rossi (toim.) Vuosikirja 2. Oulu: Oulun elokuvakeskus, 30-45.

Koivisto, Hanne (2011) Politiikkaa, erotiikkaa ja kulttuuritaistelua. Kirjoituksia suomalaisesta vasemmistoälymystöstä 1930-luvulla. Helsinki: Työväen historian ja perinteen tutkimuksen seura.

Koivisto, Hanne \& Parikka, Raimo (2015) "Espanjan sisällissota aikalaiskokemuksen, muistamisen ja tutkimuksen kohteena". Teoksessa Hanne Koivisto \& Raimo Parikka (toim.) No pasarán! Espanjan sisällissodan kulttuurihistoriaa. Helsinki: Työväen historian ja perinteen tutkimuksen seura, 7-30.

Koski, Pirkko (1987) Kansanteatteri. II osa: Helsingin Kansanteatteri. Helsinki: Helsingin Teatterisäätiö.

"Kotimainen elokuvatuotanto laajenee yhä" (1938) Suomen Sosialidemokraatti 21.8.1938, 10. 
Kotimaisia näyttämötaiteilijoita sanoin ja kuvin (1930). Viipuri: Opas.

Kujala, Antti (1995) Venäjän hallitus ja Suomen työväenliike 1899-1905. Helsinki: Suomen Historiallinen Seura.

Lammi, Emanuel (toim.) (1927) Näyttelijöitä sanoin ja kuvin. Tampere: Suomen Työväen Näyttämöiden Liitto.

Lehtisalo, Anneli (1995) Isänmaallisaiheiset historialliset elokuvat 1930-luvun lopun Suomessa. Esimerkkitapauksina Jääkärin morsian (1938) ja Varastettu kuolema (1938). Tampereen yliopisto (painamaton tutkielma).

Mickwitz, Joachim (1995) "Elokuvakerho Projektio eli kulttuuribolsevikit ja Etsivä keskuspoliisi". Lähikuva 2, 14-23.

"Näyttelijämme nykytehtävissään" (1940) Elokuva-aitta 3, 36-37.

Oittinen, Tytti (1977) "Työväen teatteritaiteen lipunkantajat". Kiilan albumi 10. Toim. Kari Sallamaa. Helsinki: Kiila, 25-38.

Ollila, Lyyli (1938) "Varastettu kuolema". Kuva 18, 32.

Pajunen, Jenny (1976) Espanja, sinä nuoruutemme. Jyväskylä: Gummerus.

Piispa, Lauri (2017) "Neuvostoelokuva 1930-luvun Suomessa". Idäntutkimus 1, 3-19.

Rantala, Raija-Sinikka (1970) Helsingin Työväen Näyttämö, 1930-luvun oppositioteatteri. Helsingin yliopisto (painamaton opinnäyte).

Rentola, Kimmo (2002) "Komintern ja Suomi 1934-1944". Teoksessa Natalia Lebedeva, Kimmo Rentola \& Tauno Saarela (toim.) Kallis toveri Stalin! Komintern ja Suomi. Helsinki: Edita.

Rinne, Matti (2006) Kiila 1936-2006. Taidetta ja taistelua. Helsinki: Tammi.

Rinne, Matti (2011) Yksitoista Tapiovaaraa: tuoleja, tauluja, elokuvia. Helsinki: Teos.

Rosenberg, Henrik (1995) Från Runar Schildts novell "Köttkvarnen" till filmen Den stulna döden: en adaptions tillkomst och tidsnivåer. Turku: Åbo akademi.

Saarela, Tauno (2002) "Kommunistinen internationaali ja suomalainen kommunismi 1919-1935". Teoksessa Natalia Lebedeva, Kimmo Rentola \& Tauno Saarela (toim.) Kallis toveri Stalin! Komintern ja Suomi. Helsinki: Edita.

Salakka, Matti (1992) "Manja ja Matti taistelevat: Varastettu kuolema ja Aktivistit historian kuvittajina". Lähikuva 4, 32-44.

Schildt, Runar (1922) "Lihamylly". Teoksessa Kotiinpaluu ja muita novelleja. Suom. Ilmari Ahma. Helsinki: Otava, 47-144.

Sedergren, Jari (1999) Filmi poikki: Poliittinen elokuvasensuuri Suomessa 1939-1947. Helsinki: Suomen Historiallinen Seura.

Sinervo, Aira (1936) "Kunnon sotamies Shvejk näyttämöllä". Kirjallisuuslehti 15.

Soikkanen, Hannu (1975) Kohti kansanvaltaa I. Suomen Sosialidemokraattinen Puolue 1899-1937. Helsinki: SDP.

Suomen kansallisfilmografia 2. Vuosien 1936-1941 suomalaiset kokoillan elokuvat (1995) Toim. Kari Uusitalo. Helsinki: Painatuskeskus.

Tapiovaara, Nyrki (1935) "Työväenteatterin tyylistä". Kirjallisuuslehti 5, 120-121.

Tapiovaara, Nyrki (1937) "Amatööri- vai ammattinäyttelijä?". Elokuva-aitta 10.

Toiviainen, Sakari (1986) Nyrki Tapiovaaran tie. Helsinki: Suomen Elokuva-arkisto.

Tossu, Gabriel (1938) "Minkälaista on elokuvanäytteleminen". Liiketyöläinen 9, 194-195.

Vala, Erkki (1934) "Helsingin Työväen Näyttämö". Tulenkantajat 20.10.1934.

Vala, Katri (1937) "Emme tahdo kuolla". Tulenkantajat 30.10.1937, 3.

"Varastettu kuolema purkeissa..." (1938) Suomen Kinolehti 5, 179.

Veistäjä, Verner (toim. 1950) Teatterin maailma: Maamme teatterit ja niiden taiteilijat. Helsinki: Tammi.

Vilenius, Lauri (1971) Erään työmiehen päiväkirjasta. Toim. Unto Miettinen. Helsinki: Otava.

Virkkunen, Sakari (1980) "Ralph Enckell - vivahteiden mestari". Suomen Kuvalehti 44, 11-14. 